\title{
Internal Exile: Effects on Families and Communities
}

\author{
Rosemary A. BArbera
}

\begin{abstract}
Military regimes throughout Latin America used a variety of tactics to instill terror in the population. In the case of Chile, the military dictatorship used torture, assassination, disappearance, exile and relegación, or internal exile, in its quest to weaken social movements and control social and economic processes. This article will discuss the effects of relegacion on the families and communities that the relegados left behind, drawing on human rights literature and interviews of persons in the Santiago shantytown of La Pincoya.
\end{abstract}

\section{Résumé}

Les régimes militaires partout en Amérique latine ont employé toute une variété de tactiques pour semer la terreur au sein de la population. Dans le cas du Chili, la dictature militaire eut recours à la torture, l'assassinat, la disparition, l'exil et le "relegación", ou exil interne, dans ses efforts pour affaiblir les mouvements sociaux et contrôler les processus sociaux et économiques. Cet article discutera des effets du "relegación" sur les familles et les communautés que les "relegados" laissèrent derrière eux, en se basant sur la littérature traitant des droits de l'homme et sur des entrevues avec des gens $d u$ bidonville de La Pincoya à Santiago.

\section{Introduction}

During the twentieth century, human rights violations and political violence ran rampant in Latin America, as in other parts of the world. ${ }^{1}$ The political violence unleashed by military regimes throughout Latin America led to immense and profound suffering throughout the continent. The military regimes used horrifically brutal techniques to subjugate those whom they considered subversive, or just to instill profound fear and insecurity in the population. These techniques included all forms of torture, mass detentions and arrests, exile, assassination, disappearance, arbitrary search and seizure operations, and internal exile, also known as relegación. Poor neighbourhoods and rural peasant communities were especially affected and afflicted by these practices. Life was disrupted, families were torn apart, and whole neighbourhoods and communities were physically and psychologically destroyed. Such was the situation in Chile.

This article will specifically address how the human rights violation of relegación in Chile affected families and the social fabric of communities. Relegación, or internal exile, was the practice used by the military regime in Chile of sending someone, usually a well-known community leader, to a remote part of the country, effectively cutting her/him off from their natural systems of support. At the same time, relegación left many opposition organizations without their leaders, thereby weakening the opposition to the Pinochet regime.

The topic of relegación has not been widely studied and there are scarce references in the literature to relegación. This article will attempt, using information gathered in intensive interviews in the Chilean shantytown (población) of La Pincoya, to contribute to the literature to understand the effects of relegación. A number of key leaders in La Pincoya were subjected to relegación during the military regime. Their neighbours and family members remember the personal and communal loss this relegacion had on the community and its organizations.

\section{Review of the Literature}

And there they were, numbed in their millennial and captivating pain. They were there, inclined, dangling in an invisible net of suspended time. I approached them. I wanted to speak with them, but what could I ask them? How could I comfort them? By what right could I enter lives sealed by political violence? 
How to ask then what it means to be the mother of a disappeared? Of a political prisoner? Why should I see them cry? ? $^{2}$

The above quotation from noted Chilean author Marjorie Agosín captures the essence of the consequences of human rights abuses across systems levels. "Dangling in an invisible net of suspended time" is how many people discuss the effects of relegacion; they felt that while their loved one or neighbour was internally exiled, life was on hold. In La Pincoya many feel that the advancements of their neighbourhood were brutally and violently truncated by the military coup on 11 September, 1973, and with that they feel like they are stuck in time, that their lives are sealed by political violence. The regime of Augusto Pinochet "attempted to desarticular ${ }^{3}$ the former society" 4 and erase its former social and economic achievements, including those achievements of the residents of La Pincoya. A variety of methods were used by the Pinochet regime to desarticular the community, including the human rights violation of relegación.

There are a number of ways to conceptualize the legacy of human rights violations. ${ }^{5}$ These include addressing the issue from the perspective of trauma and examining the literatures of trauma and disaster. ${ }^{6}$ Another way to conceptualize this issue is to examine literature that relates to psychological effects including self-concept and the way an individual conceives of her or himself. ${ }^{7}$ Grief and guilt are a third way to examine this phenomenon. ${ }^{8}$ A fourth way to conceptualize this area is to look at the loss of community ties and social capital that one may experience after a trauma. ${ }^{9}$ And a fifth perspective is that of examining the survivors' ongoing participation in society. The focus of this study is informed by all of these perspectives, with a special emphasis on collective action and community involvement, particularly with an eye on how communities demonstrated resiliency despite the incredibly harsh conditions under which they lived. Much research and writing have been done examining how human rights violations might affect an individual's functioning; however, the literature is sparse when looking at community in the midst and after human rights abuses. ${ }^{10}$

Human rights violations are social phenomena. Therefore they have societal implications for individual survivors and society at large. ${ }^{11}$ These violations are both an assault on the human rights of individuals and an attack on the rights of the society. Relegación, for example, has significant repercussions on the social fabric of society as the act of relegación extends beyond the person being exiled to that person's networks. The relegación serves to instill fear and to send a clear message that anyone who voices disagreement with the regime and its practices could also find themselves in a similar situation. It also sends an insidious message of fear - fear of harm, and fear of trusting one's neighbours, co-workers, and friends. In this way, its tentacles reach far beyond the victim/survivor to the community at large, enforcing a "rupture in the normal process of life, a rupture that is forced from the outside, from the dictatorial state, whose acts violently and abruptly disturb human life." 12

The process of relegación, which consisted usually of arrest, torture, and internal exile, also involves trauma at many levels.

Trauma is generally taken to mean a blow to the tissues of the body - or more frequently now, to the tissues of the mind - that results in injury or some other disturbance. Something alien breaks in on you, smashing through whatever barriers your mind has set up as a line of defense. It invades you, takes you over, becomes a dominating feature of your interior landscape - 'possesses' you - and in the process threatens to drain you and leave you empty. ${ }^{13}$

So, trauma is both the cause of the event (the blow) and the subsequent condition that results. It affects the traumatized in mind, body and spirit. As Erikson says, it is an invasion that permeates all aspects of life and becomes a defining feature.

Since humans are social beings, this trauma can be understood not only as an assault on the individual person, but as an assault on the links and connections between people and the patterns of relationships through which people define themselves and give meaning to their lives. ${ }^{14}$ This is a trauma "provoked by human violence, consciously and meticulously planned"15 by the state and the apparatus of the state. ${ }^{16}$ This has clear implications for community involvement. The quality of the life of the community is affected by the quality of life of its members and the community suffers as individuals suffer and as society redefines itself; what is inflicted on one part of the body, affects other parts. ${ }^{17}$

In Chile, the processes of arrest and torture, followed by disappearance, exile, or relegación, were part of a larger process of collective terrorism intended to provoke "generalized fear and collective anxiety" 18 in the population. The purpose was to infuse all aspects of life with fear so that fear permeated society and immobilized possible resistance to the military regime. These forms of political repression often cut a person off from social support systems as well as altering her or his relationship to the larger society. ${ }^{19}$ The sense of trust in the community was disabled, at best, and shattered, at worst, in this process. Therefore, community members were no longer able to rely on the forms of social capital upon which they previously counted. Possibilities for participation and social interaction decreased and frustration ensued. According to Doménguez and Weinstein, the boundaries between what was safe and what was dan- 
gerous were no longer clear. This affected the person's sense of social belonging.

In the community, a traumatic event may lead to the breakdown of social codes and networks. This, of course, has significant implications for how a community functions and its ability to mobilize to overcome the trauma. Since, as Oxhorn ${ }^{20}$ suggests, the emergence of social organizations in Chile had to do with social relations, the breakdown of social codes and networks that resulted from the practices of the military regime debilitated those social relations. This was particularly true in the Chilean poblaciones where neighbours lived piled upon one another, in close quarters and always in need. The close proximity of their living conditions, as well as their great economic need, drew people together as allies, trying to jointly solve their problems. It was because of these networks of neighbours during the dictatorship that the fabric of civic life was not completely destroyed and could carry on, at least for some members of society. Oxhorn also points out that the idea of "community was virtually synonymous with friendship and a sense of 'belonging."'21 Therefore, when a key member of the community was taken away and sent into relegacion, the entire community was deeply affected.

This concept of community has been integral. It is through community that members have been able to get their physical, emotional, and psychological needs met. ${ }^{22}$ This concept included the idea of solidarity, which is central in Chile, and the idea of collective action, which meant putting the needs of the group over individual concerns. ${ }^{23}$ The military regime aimed to destroy the ties of community and to force an individualistic mentality upon Chileans in order to cure the society of what the regime considered to be the "cancer of communism." Therefore, instead of turning to neighbours and community members to help meet their needs, individuals were now forced to rely upon themselves. Slowly they lost the habits of solidarity and collective action as they witnessed and experienced human rights abuses and fear increased.

"The Southern Cone Military regimes, more than other dictatorships, were institutionalized systems that deliberately produced and spread fear." ${ }^{24}$ These military regimes operated under a National Security Doctrine that broadly defined risks to security and instilled comprehensive fear in the majority of the population. In Chile "the entire population was affected directly by the repressive acts of the state" 25 in the name of national security. Since the National Security Doctrine of the regime had as its goal to change the way Chileans thought, they used every means at their disposal to do so. This led to the internalization of fear, loss of group identities, devastation of social organizations, and a diminishing of the capacity to engage in activities of soli- darity. Fear "was instilled both directly and indirectly in society as a whole through the combined effect of repressive policies, the absence of institutional protection, and the superimposed model of social transformation." 26 Therefore, fear became a defining reality in daily life in Chile, and in the interactions between ordinary Chileans and the established state institutions. Violence - "an historical structural violence" 27 - imposed fear of the very state charged with caring for the people.

The authoritarian regime in Chile "created a culture of fear" 28 that guided the actions, reactions, interactions, and even thoughts of the populace. It was a culture of fear that permeated all aspects of life and living and did not allow people to feel safe, even in their own homes with their own families. Corradi, Gagen, and Garréton explain it in the following way:

For decades, the populations of many countries have been subject to generalized or centralized violence; they have experienced the erosion of public values, of legal and even primary social bonds. Uncertainty, self-doubt, insecurity have been the staples of public life. In such contexts, fear is a paramount feature in social action: it is characterized by the inability of social actors to predict the consequences of their behavior because public authority is arbitrarily and brutally exercised. ${ }^{29}$

The unpredictability of the reactions of the military regimes, along with the ongoing, strategically executed campaign of terror, led to further incapacitation of social life and social organizations throughout Chile. The perfection of state terrorism led to societies embedded in fear - it eliminated safe spaces where people could join together in solidarity; " people have become trapped in the fear of fear"31 which then rendered them isolated, terrorized, and debilitated. Or, as Rojas points out, "although we are not all the direct victims of the regime, we have all been submitted to the terror, the fear, the psychological manipulation, the human transfiguration" 32 that led us to live in a constant state of internalized fear.

Relegacion is one way that the state inflicts terror on the population in order to diminish dissent and achieve social control. All forms of human rights violations increase vulnerability, including relegación. With relegación, "people are deprived of their homes, communities and means of livelihood." 33 At the same time, communities are deprived of their leaders. As the data will show, this was certainly true in the población La Pincoya ${ }^{34}$ in Santiago, Chile, one of neighbourhoods that tried to resist the Pinochet regime. According to Ariel Dorfman, 
internal exile ... has immense advantages for the dictatorship. It disrupts and neutralizes the dissident movement by sending some of its most militant members to faraway places, where they lose contact with what is going on. The whole country become a prison, and it costs the state nothing. . . nor are the effects on the permanent inhabitants of those remote places to be overlooked: there for all to see, is proof of the government's omnipotence. $^{35}$

Through massive human rights violations, the regime was able to warn the population not to engage in dissent, or they would suffer the consequences. The dictatorship did so in such a way as to "control the public space and reduced communication so that people could not address their problems collectively," making people feel "like caged animals."36

As the literature demonstrates, the effects of widespread human rights abuses in Chile reach far beyond those physically harmed; the Pinochet regime aimed to affect quotidian life in a such a way as to dismantle community ties and break down networks of solidarity. Relegación served the purposes of the military as it contributed to the desarticulación of opposition organizations as well as spreading fear in the general population.

\section{Methodology}

The research method used for the present study was a qualitative design which made use of intensive interviews, participant observation, and case studies. The researcher has been a resident of La Pincoya since 1987 and has participated actively in community and human rights organizations since that time. Research began by asking permission to interview community leaders who had family members who were relegados ${ }^{37}$ since the focus of the research was on the effects of the relegación for those left behind. These leaders, in turn, supplied the researcher with the contact information of other families who had a member relegado, thus making use of a snowball sample. Likewise, the researcher interviewed community leaders who had participated in community organizations with relegados in order to learn the effects of relegación on the community. They, too, supplied more contacts, again using a snowball sampling method.

Simultaneously with conducting intensive interviews, the researcher was also actively engaging in participant observation. She attended community meetings and accepted offers to have onces ${ }^{38}$ at people's homes in order to ask them about their memories of relegados, human rights violations, and the community in general. She also contacted people who had worked as social workers, therapists, organizers, and in other capacities in the human rights field during the military regime to ask for their impressions of relegación and its effects on communities and families.

\section{Relegación}

In Chile, internal exiles were sent to all different parts of the country, usually to isolated small towns that were difficult to reach and far from public transportation. It was as if the dictatorship used the geography of Chile as a form of exile. ${ }^{39}$ According to Lorena, ${ }^{40}$ whose husband was sent into relegación multiple times:

They sent them to the north, the south, wherever, and all of the towns were tiny and far away. For the people that were from small towns, it was easier. But for those who were from a city, it was a difficult adjustment. For everyone it was difficult being so far removed from family, friends, support systems and networks. There were usually no telephones and it was difficult to communicate with family members. ${ }^{41}$

Juan, Lorena's son, continues: "It was tough for us kids growing up not knowing where our father was. One day he was with us, the next our home was violently invaded by the police and out father was taken away." 42 In most cases, families were not given information about a possible court date for their loved one's case, and if they were lucky, they might be able to wave goodbye as their loved one left the courtroom and was sent to the far reaches of Chile.

Once the person arrived at the destination of their relegación, adjustment began. But it is here that an interesting phenomenon occurred. According to Manuel, who was relegado on more than one occasion, the "town people demonstrated solidarity with the relegados by bringing us mattresses, food, and welcoming us into the town. It was their own, significant way of dissenting from the military regime. In fact, they even saved the best eggs for us." ${ }^{33}$ This is not to say that life was easy; it was not. However, there were humane gestures that helped make the difficult situation a little less difficult.

\section{Effects on Families}

Meanwhile, families were left to wonder about their loved ones. With the help of the Vicaría de la Solidaridad, the Roman Catholic Church's human rights organization, they were able to eventually find out where their loved ones were. The Vicaría at times even provided bus tickets for family visits. These trips, however, were quite stressful. Carmen remembers once when she was going to visit her husband, Fernando: "The Vicaría gave us bus tickets to travel to this far away place to visit Fernando. When we got there, he was not there and no one knew anything about him. We were terrified that he had been killed or disappeared." ${ }^{44}$ Lorena remembers that this was so stressful for her and her four children. "We did not know where they were taken. We were lucky because we saw them being taken from the jail, at 6:00 
in the morning, but after that we did not find out for weeks where they were and how they were." 45 Families lived with permanent stress and uncertainty.

This stress was caused by multiple factors. First, families were affected financially because, in many cases, the primary breadwinner was no longer contributing financially. Lorena comments, "I had to scramble to find a job and provide for our family. I had to accept double shifts in order to earn enough money so that we could survive in Santiago, and to send supplies to my husband." 46

Second, as the family tried to scramble to adjust, children often felt abandoned as one parent took over the responsibilities of two. Marcos remembers, "The time they took my father, my mother spent so much time working, we were always left alone at home. We had to fend for ourselves. Then, when my mother was taken away, it got even worse." ${ }^{47}$ Juan add,: "We were told that our parents were delinquents and common thugs. We suffered a lot because of that."

And, third, many families found that their status in the community was significantly altered as other families avoided them for fear that they too would be targeted for persecution. Rosa remembers that "neighbors no longer engaged in conversation with me. Sure, they said hello to me and commented about the weather, but the conversations stopped there." 48 Mónica adds, "I could no longer count on my neighbors to help watch my kids or with other chores. This was really tough on me since my children were small and I had to work outside of the house. I understand that they were afraid, but just the same, it was difficult." 49

\section{Effects on Communities}

Just as families suffered with the relegacion of a loved one, communities also suffered when their leaders were taken away. Johnny remembers what it was like when the leader of the youth group he participated in was taken: "When they took Fernando from us, we were devastated. He was like a father-figure to all of us; we knew he really cared about us. In retrospect, I now realize that we were not the only ones who suffered during his relegación." 50 What Johnny alludes to here is the fact that Fernando was the leader of a local opposition political party. In that capacity he helped lead protests, educate youth, and organize the neighbourhood. His loss was felt strongly by the community. When his wife Lorena was taken, the community also suffered. Lucy recalls:

Lorena was a protagonist in this community from day one. She helped lead the land invasion that gave birth to La Pincoya and from that moment forward she has been a leader. She led the drive for health care for our new neighborhood, and then when the dictatorship took away our access to health care, she organ- ized grass-roots health groups so that people could get their needs met. ${ }^{51}$

When asked about how the community suffered, Lorena, Johnny, and others agreed that La Pincoya was targeted for repression because it had a history of protagonism. Leaders like Lorena and Fernando were integral parts of that protagonism and their absence was deeply felt. "People no longer wanted to get involved because they were scared, and they missed the leadership of Lorena and Fernando," said Tamara. ${ }^{52}$

\section{Discussion}

The data show us the intersection and contradiction between vulnerability and resilience. People like Lorena and Fernando both were in vulnerable situations because of their political and social commitments and demonstrated incredible resilience despite the consequences. This has serious implications for human rights, social service, and psychosocial workers in communities that have been torn apart by political violence because it shows that, despite repression, people can still be the protagonists of their own lives and that natural indigenous leaders can significantly improve the relations of a community.

Another way in which vulnerability and resilience were demonstrated was in the ways that the families of relegados joined together in solidarity, again despite the potential harsh consequences. Families were able to go beyond their own fear and pain and join together to work for the freedom of their loved ones. Lorena commented, and began to cry:

People demonstrated great solidarity with us. They had their own troubles, but still reached out to us because we had more children and more needs. One old man brought me six rolls every day; another gave me 500 pesos. These were family members of people who had suffered, or they themselves had suffered. They had everything to fear, but they were moved beyond their fear, unlike our neighbors who remained distant and afraid. $^{53}$

This is a clear example of how, despite terror and trauma, people are quite resourceful. Human rights, social service, and psychosocial workers can learn a great deal from this example in order to provide better services and work in solidarity with communities that are dealing with the effects of human rights abuses; we can learn to focus on the strengths of individuals and communities, rather than the weaknesses or the assumed pathologies. The literature is replete with discussions of trauma and its effects; this is a focus on pathologies rather than on strengths. This also assumes a certain Western/Northern interpretation of the 
world ${ }^{54}$ that prioritizes the interpretation of "professionals" over the experiences of the people. We need to let go of the biases that our Western/Northern education has forced upon us in order to work in partnership with affected communities using their local knowledge and strengths as the starting point for our work.

We can also learn that the saying "give voice to the voiceless" is at best a misnomer, and at worst patronizing; everyone has a voice, it is just that some voices are heard while others are not. Instead of focusing our work on being ventriloquists ${ }^{55}$ and speaking for others, we can help create the conditions where all voices are heard and respected. That is, we can use our privilege in the service of vulnerable populations to work with them as they increase their resilience, or, better yet, do away with the very conditions which necessitate resilience in the first place.

\section{Conclusion}

The human rights violations of the military regime in Chile caused significant damage to the social fabric of society. Whereas Chile's history of organizing for social change dates back almost to the founding of the republic, the military regime aimed to destroy the solidarity and community ties that made organizing possible. As a result, many people no longer trusted one another and did not want to get involved in collective organizations, especially if the leaders of those organizations had been targeted for repression. The relegación of many leaders in the población La Pincoya led to an increase in vulnerability in families and community organizations that now found themselves without their leaders. There was, as a result, a loss of community participation as people were afraid to participate for fear they, too, would be targeted. At the same time, for a small but significant part of the population there was an increase in resilience and resistance. Despite the fact that people's sense of power to be actors in their own lives and the lives of their community was violently attacked, some people still participated, organized, protested, and worked to overthrow the military regime of Pinochet.

These people, like Lorena, Fernando, Carmen, Manuel, and others, continued to organize, agitate, and fight for human rights. They suffered, as did their families, but they did not compromise their values. Each one of them was arrested, tortured, and sent into internal exile, in the far reaches of Chile. Despite their increased vulnerability, they were resilient and determined to continue the fight for a democratic Chile where human rights were respected. They, like many refugees throughout the world, are protagonists of change and examples of resilience. We can learn from their courage, resilience, and example. And, we can apply what we learn to our work with vulnerable populations around the globe.

\section{Notes}

1. Nancy Hollander, Love in a Time of Hate: Liberation Psychology in Latin America (New Brunswick, NJ: Rutgers University Press, 1997).

2. Marjorie Agosín, Ashes of Revolt: Essays on Human Rights (Fredonia, NY: White Wine Press, 1996), 53.

3. The term "desarticular" has no direct translation into English but refers to a process of disarming, dismantling, incapacitating. Where this term was originally used in Spanish I have kept the word in Spanish. The state's attempt to desarticular community connections and organizations through the use of terror, torture, relegación, and other means led to increased vulnerability for refugees, internal exiles, and their families and communities since people were isolated from their support systems.

4. Manuel Antonio Garretón, "Fear in Military Regimes: An Overview," in Corradi, Gagen, and Garretón, eds., 13-25.

5. Mario Vidal, Lo igual y lo distinto en los problemas psicopatologicos ligados a la represión politico [What Is the Same and Different in Psychopathological Problems Associated with Political Repression] (Santiago: CINTRAS, 1993).

6. Bessel A. van der Kolk and Alexander A. McFarlane, Traumatic Stress: The Effects of Overwhelming Experience on Mind, Body, and Society (New York: Guilford Press, 1996).

7. Eugenia Weinstein and Elizabeth Lira, "La Tortura" [Torture], in Trauma, duelo y reparación: Una experiencia de trabajo psicosocial en Chile [Trauma, Grief and Reparation: An Experience of Psychosocial Work in Chile], ed. Fundación de Ayuda Social de las Iglesias Cristianas (FASIC), (Santiago: Editorial Interamericana, 1987): 33-94.

8. Inger Agger, The Blue Room: Trauma and Testimony among Refugee Women - A Psycho-social Exploration (London: Zed Books, 1992); see also Weinstein and Lira.

9. Kai Erikson, "Notes on Trauma and Community," in Trauma: Explorations in Memory, ed. Cathy Caruth (Baltimore, MD: Johns Hopkins University Press, 1995), 183-199; see also Erikson, Everything in Its Path: Destruction of Community in the Buffalo Creek Flood (New York: Simon \& Schuster, 1976).

10. María Teresa Almarza, "Aspectos psicosociales de la represión durante la dictadura" [Psychosocial Aspects of Repression during the Dictatorship], Reflexión 110 (1990): 15-20; see also Judith Herman, Trauma and Recovery: The Aftermath of Violence - from Domestic Abuse to Political Terror (New York: BasicBooks, 1992); Elizabeth Lira and Eugenia Weinstein, Psicoterapia y represión [Psychotherapy and Repression] (Mexico: Siglo Veintiuno Editores, 1984); and Mario Pinto and Ignacio Salas, "Interacción profesional en salud mental y derechos humanos: Un enfoque sistemico" [Mental Health Professional Interaction and Human Rights: A Systemic Focus], Reflexión 18 (1993): 6-10. 
11. Elizabeth Lira and María Castillo, Psicología de la amenaza política [The Psychology of Political Threats] (Santiago: Instituto Latinoamericano de Salud Mental y Derechos Humanos, 1991); see also Elizabeth Lira, Brian Loveman, Tony Misfud, and Pablo Salvat, Historia, politíca, yética de la verdad en Chile, 18910 2001: Reflexiones sobre la paz social y la impunidad [History, Politics and Ethics of the Truth in Chile, 1891-2001: Reflections about Social Peace and Impunity] (Santiago, Chile: LOM Ediciones, 2001); Weinstein and Lira.

12. Comité de Defensa de los Derechos del Pueblo (CODEPU), Crimenes e Impunidad: La Experiencia del Trabajo Médico, Psicológico, Social y Júridico en la Violación del Derecho a la Vida, Chile 1973-1996 [Crimes and Impunity: The Experience of Medical, Psychological, Social and Legal Work in Relation to the Right to Life, Chile, 1973-1996] (Santiago: LOM Ediciones, 1996).

13. Erikson, "Notes on Trauma and Community."

14. Agger; see also van der Kolk and McFarlane, 1996.

15. Comité de Defensa de los Derechos del Pueblo (CODEPU).

16. Paz Rojas, "Horror y olvido. Violencia de estado, derechos humanos y salud" [Horror and Forgetting. State Violence, Human Rights and Health], in Persona, estado, poder: Estudios sobre salud mental Volumen II, Chile 1990-1995 [Person, State, Power: Studies on Mental Health, Volume II, Chile, 1990-1995], ed. Comité de Defensa de los Derechos del Pueblo (CODEPU), (Santiago, Chile: Ediciones LOM, 1996), 63-71.

17. Daniel Bar-On, The Indescribable and the Undiscussable: Reconstructing Human Discourse after Trauma (Budapest: Central European University Press, 1999); see also Allan Young, "Suffering and the Origins of Traumatic Memory," Doedalus 125 (1996): 245-260.

18. Comité de Defensa de los Derechos del Pueblo (CODEPU).

19. R. Doménguez and Eugenia Weinstein, "Aiding Victims of Political Repression in Chile: A Psychological and Psychotherapeutic Approach," Tidsskrift for Norsk Psykologforening 24 (1987): 75-81.

20. Philip Oxhorn, Organizing Civil Society: The Popular Sectors and the Struggle for Democracy in Chile (University Park, PA: Pennsylvania State University Press, 1995).

21. Ibid., 115.

22. Almarza.

23. Oxhorn.

24. Garretón.

25. Luis Ibacache, Jaime Meléndez, Luisa Castaldi, Margarita Cabrera, and Hector Vega, "Las huellas del miedo. La represión política: Daño y reparación” [The Footprints of Fear. Political Repression: Harm and Reparation], in Persona, estado, poder: Estudios sobre salud mental Volumen II, Chile 1990-1995 [Person, State, Power: Studies on Mental Health, Volume II, Chile, 1990-1995], ed. Comité de Defensa de los Derechos del Pueblo (CODEPU), (Santiago, Chile: Ediciones LOM, 1996), 29 - 39.

26. Garretón.

27. Rojas.
28. Norbert Lechner, "Some People Die of Fear: Fear as a Political Problem," in Corradi, Gagen, and Garretón, eds., 26 - 35.

29. Juan Corradi, Patricia Weiss Gagen, and Manuel Antonio Garretón, eds., Fear at the Edge: State Terror and Resistance in Latin America (Berkeley, CA: University of California Press, 1992).

30. Dirk Kruijt and Kees Koonings, "Violence and Fear in Latin America," in Societies of Fear: The Legacy of Civil War, Violence and Terror in Latin America (New York: Zed Books, 1999) $1-31$.

31. Ibacache et al.

32. Rojas.

33. Thomas G. Weiss, "Internal Exiles: What Next for Internally Displaced Persons?" Third World Quarterly 24 (2003): 429-447.

34. The history of La Pincoya is fascinating and filled with protagonism. La Pincoya is the product of years of community organizing, culminating in a series of land invasions in 1968. For more detail on the history of La Pincoya see Rosemary Barbera, "From Protagonists to Spectators and Back Again? The Legacy of the Chilean Military Dictatorship on Community Participation in La Pincoya" (doctoral dissertation, Bryn Mawr College, 2003); and Mario Garcés, "Memoria, identidad e historia local" [Memory, Identity and Local History\} (paper presented at the meeting Proyecto Desarrollo de Capacidades parra la Integración MERCOSUR, Asunción, Paraguay, May 2000).

35. Ariel Dorfman, "Into Pinochet's Chile: Return to a Country of Exiles, Part I," The Nation, April 13, 1985.

36. Ariel Dorfman, "Into Pinochet's Chile: In Search of Internal Exiles, Part II,” The Nation, April 20, 1985.

37. Those who have been sent into relegación.

38. Onces is the evening meal which consists of tea and bread.

39. Dorfman, "Into Pinochet's Chile: In Search of Internal Exiles, Part II.”

40. Names have been changed at the request of participants.

41. Interview with "Lorena," August 20, 2006.

42. Interview with "Juan," August 20, 2006.

43. Interview with "Manuel," May 8, 2006.

44. Interview with "Carmen," August 25, 2006.

45. Lorena.

46. Ibid.

47. Interview with "Marcos," May 8, 2006.

48. Interview with "Rosa," August, 25, 2006.

49. Interview with "Mónica," August 25, 2006.

50. Interview with "Johnny," August, 24, 2006.

51. Interview with "Lucy," August 24, 2006.

52. Interview with "Tamara," August, 26, 2006.

53. Lorena.

54. Ignacio Martín-Baró, Writings for a Liberation Psychology (Cambridge, MA: Harvard University Press, 1994).

55. Michelle Fine, "Walking the Hyphens: Reinventing Self and Other in Qualitative Research," in Handbook of Qualitative Research (Thousand Oaks, CA: Sage Publications, 1994) 70 -82 . 


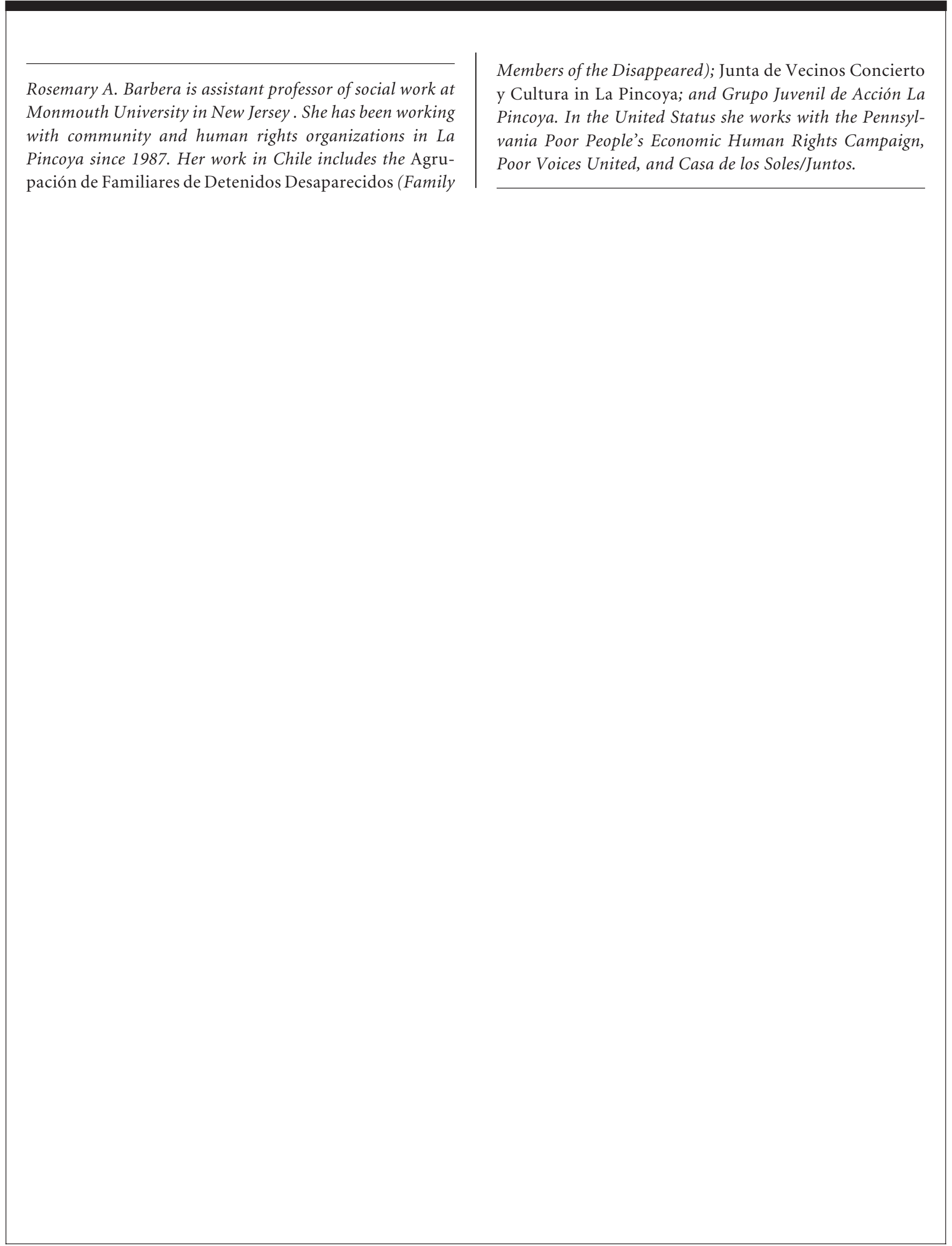

(C) Rosemary A. Barbera, 2008. This open-access work is licensed under a Creative Commons Attribution-NonCommercial 4.0 International License, which permits use, reproduction and distribution in any medium for non-commercial purposes, provided the original author(s) are credited and the original publication in Refuge: Canada's Journal on Refugees is cited. 